\title{
Study of Hygral Behavior of NON-asbestos Fiber Cement Made by Similar Hatschek Process
}

\author{
Carlos Eduardo Marmorato Gomes ${ }^{\mathrm{a} *}$, Holmer Savastano $\mathrm{Jr}^{\mathrm{b}}$ \\ a Department of Architecture and Construction, School of Civil Engineering, \\ Architecture and Urban Design, University of Campinas - UNICAMP, Campinas, SP, Brazil \\ ${ }^{\mathrm{b}}$ Rural Construction Group, Department of Food Engineering, \\ College of Animal Science and Food Engineering - FZEA, \\ University of São Paulo - USP, Pirassununga, SP, Brazil
}

Received: January 21, 2013; Revised: October 1, 2013

\begin{abstract}
Fiber cement, similarly to all cementitious materials, undergoes dimensional and volumetric changes when it is exposed to dry and wet environments. When exposed to natural weathering, cement-based materials absorbs and may also release water to their surroundings via a very complex inherent pore structure. In this work initialized a few years ago, some properties of asbestos-free fiber cement composites were studied, such as density, porosity and loss or absorption of water. For the understanding of the behavior of this material, modifiers were employed in the cement matrix such as styrene- acrylic, styrene-butadiene and vinyl acetate-versatic vinylester copolymers to verify their influence on the variables described above. All composites were analyzed by mercury intrusion porosimetry (MIP). For monitoring the expansion/shrinkage movements, the specimens were exposed inside a controlled environmental chamber with constant temperature and relative humidity $(\mathrm{RH})$ during the test time. The results showed no interference on hygral behavior because particular casting process of these composites but, as showed by literature, increase of toughness. Also, it was possible to verify that moisture movement within the asbestos-free fiber cement can be very complex and the variables density and porosity (pore structure) play a very important role in the expansion/shrinkage properties of these composites.
\end{abstract}

Keywords: copolymers, fiber cement, moisture movement, expansion/shrinkage

\section{Introduction}

Cement-based composites exposed to natural weathering absorb water and may also release water to the surroundings via a very complex inherent pore structure. The extent of pore water exchange and the speed at which it occurs depend on numerous factors ${ }^{1}$, for example, the type of application (roofing or steel frame system), the shape of the product, the temperature of the surrounding environment, the relative humidity, the weather conditions, the porosity and pore structure of the material, the orientation of structure (anisotropy), the type of fiber (cellulose or synthetic), the type of coating or impregnation applied and the age of material.

After fiber cement undergoes expansion or shrinkage it may produce cracking and also to be aesthetically displeasing and eventually can lead to structural unsoundness and poor durability in a component. In Brazil, frequently failures have been observed in joints of asbestos-free fiber cement sheets because the excessive moisture movements of these composites.

Various forms of shrinkage are associated with cementitious materials and since drying shrinkage is among the most troublesome, it is a useful tool for the performance evaluation in the development of improved materials.

*e-mail: cemgomes@fec.unicamp.br
It is evident from the factors mentioned above that it would be an extremely difficult task to describe the exchange of water in the pores of cement-based fiber composite during exposure to natural weathering. In fact not much has been reported in the literature regarding the moisture movement of asbestos-free fiber cement.

In general, it is observed that in concrete the presence of large volume fractions of rigid aggregates retrains the amount of moisture-induced movements. In fiber cement composites the volume concentration of fibers is very low compared to the aggregate volume and the matrix tends to be slightly richer in binder in comparison with normal concrete.

Although the transportation of pore water in fiber cement composites is complex, it is important to describe in general terms the behavior of the material under certain climatic conditions as the exchange of water in the pores results in dimensional changes (expansion or shrinkage) within the product. It is the reason for the study of the effect of water movement within the composites.

This paper shows the influence of density, porosity (pore structure) and sorption of water in the moisture movements of asbestos-free fiber cement where exchanges in these variables were made by the use of different copolymers. 


\section{Literature Review}

\subsection{Asbestos-free fiber cement composites}

Over the last decades many research studies related to the substitution of asbestos by other raw materials have been published. In this way, natural fibers from different softwood and hardwood species and synthetic fibers such as polypropylene (PP) and polyvinyl alcohol (PVA) have been an important group of studied fibers.

Natural fibers are frequently characterized by the low cost and poor durability because of vulnerability to chemical decomposition in the alkaline environment of cement. Regardless, these fibers are very important in countries with agricultural based economies ${ }^{2}$.

Synthetic (polymeric) fibers have become more attractive in recent years for reinforcement of cementitious materials. In this way, PP and PVA have been studied extensively, with fibers formulated and produced specifically for reinforcement of cement-based composites. However, polymeric fibers present low modulus of elasticity compared to asbestos. To increase the strength of the composites, the fibers must have a modulus of elasticity greater than that of matrix. For cementitious materials, where the modulus de elasticity ranges from approximately 15 to $30 \mathrm{GPa}$, this condition is difficult to meet with synthetic fibers. Moreover, fiber-matrix interface may constitute a problem to the engineering of these composites ${ }^{3}$.

Asbestos is a natural occurring fibrous silicate very compatible with cement. Its chemical structure and its fiber size make composites of higher strength and lower moisture movements than asbestos-free cement-based composites.

This situation confirms the importance of understanding the hygral behavior of these composites, one of the most important variables for asbestos replacement, principally in applications such as corrugated sheets for roofing and flat sheets for dry-wall buildings.

\subsection{Polymer addition}

The concept of polymer modification is well known and the first patent was obtained in 1923. This patent refers to the use of cement as filler in polymer matrix. In 1924, the first patent was published using the concept of polymer modification for cement mortar and concrete ${ }^{4-7}$.

As a principle of polymer modification, it is very important that both Portland cement hydration and polymer film formation proceed well in order to produce a monolithic matrix phase with a network structure in which the cement hydrate phase and polymer phase interpenetrate. The modification with redispersible polymer powders is similar to that of latex formation except that it also involves the redispersion of the polymer powders ${ }^{8-15}$. In these cases, the modification is governed by both Portland cement hydration and polymer film formation processes in their binder phase ${ }^{16-22}$. The cement hydration process generally precedes the polymer film formation by coalescence of polymer particle.

According to the theory, during the hydration of Portland cement the hydrophilic part of the polymer is oriented towards the water phase whereas the hydrophobic part heads towards the air phase (pores and capillaries not pilled with water). Upon drying, the water is taken away and the hydrophobic particles coalesce together and form the film.

Drastic changes in the matrix properties such as density and porosity can be achieved by combining the matrix with polymers and it can also reduce the shrinkage of the composites $^{3}$. It is the reason by which in this work the polymer addition is showed as one alternative to the studies of moisture movements of non-asbestos fiber cement. Due to their hygroscopic nature, fiber cement composites are sensitive to moisture changes in the material and in the ambient environment. Several studies have been conducted to assess the performance of pulp fiber-cement composites under different moisture states, particularly in the wet and oven-dry states.

It was possible to verify in the literature some works about polymer-modified cement matrix reinforced by E-glass and neither about other kind of fiber. As related ${ }^{23}$, the GRFC (Glass Fiber Reinforced Cement) was developed by Bijen and Jacobs using a special acrylic polymer (Forton) which was developed for that purpose. In the production of this composite, the tiny polymer latex particles infiltrate and fill the spaces between the filaments in the strand and eventually coalesce into a film. Thus they can provide a protective effect, both o reduce the chemical attack, and to reduce the extent of the microstructural mechanism, by eliminating the growth of dense and rigid hydration around the filaments. Also, some authors describe the formation of the film in the matrix provide an additional sealing effect to slow down moisture movement, and consequently the expansion/shrinkage of fiber cementitious composites ${ }^{24-27}$.

\section{Experimental}

\subsection{Material}

The materials employed for composite preparations were Portland Slag Cement according to EN 1971 - European Standards ${ }^{28}$ - type (CEM II /B-S), cellulose pulp (solombola, Russian specie), Chinese PVA fibers (length: $6 \mathrm{~mm}$; diameter: $20 \mu \mathrm{m}$ ), carbonate powder as inert filler, silica fume and styrene-acrylic, styrene-butadiene and $\mathrm{Va} / \mathrm{Veova}$ copolymers. Some characteristics of these materials are shown in Tables 1-6.

Table 1. Chemical analysis of Portland cement.

\begin{tabular}{|c|c|c|}
\hline \multicolumn{3}{|c|}{$\begin{array}{c}\text { Chemical analysis of ordinary Portland cement } \\
\text { (\% by mass) }\end{array}$} \\
\hline Element & $\begin{array}{c}\text { Average of } 4 \\
\text { analyses }\end{array}$ & $\begin{array}{l}\text { Standard } \\
\text { deviation }\end{array}$ \\
\hline $\mathrm{SiO}_{2}$ & 19.52 & 0.10 \\
\hline $\mathrm{Al}_{2} \mathrm{O}_{3}$ & 5.03 & 0.05 \\
\hline $\mathrm{Fe}_{2} \mathrm{O}_{3}$ & 3.02 & 0.04 \\
\hline $\mathrm{CaO}$ & 64.76 & 0.10 \\
\hline $\mathrm{MgO}$ & 0.62 & 0.03 \\
\hline $\mathrm{SO}_{3}$ & 2.85 & 0.03 \\
\hline $\mathrm{CO}_{2}$ & 2.25 & 0.28 \\
\hline $\mathrm{K}_{2} \mathrm{O}$ & 0.70 & 0.01 \\
\hline Loss on ignition & 2.86 & 0.16 \\
\hline Residue & 0.27 & 0.03 \\
\hline
\end{tabular}


Table 2. Physical characteristics of styrene-acrylic copolymer dispersion.

\begin{tabular}{lc}
\hline \multicolumn{2}{c}{ Physical analyses } \\
\hline Solids content $(\%$ by mass) & $50 \pm 1^{*}$ \\
Viscosity (MPa.s) & $2,000-5,000$ \\
Glass Transition $\left({ }^{\circ} \mathrm{C}\right)$ & $\sim-8$ \\
Apparent density $\left(\mathrm{g} / \mathrm{cm}^{3}\right)$ & $1.0 \pm 0.1^{*}$ \\
Particle size $(\mu \mathrm{m})$ & $80 \pm 10^{*}$ \\
\hline
\end{tabular}

*Standard deviation.

Table 3. Physical characteristics of Va/Veova copolymer powder.

\begin{tabular}{lc}
\hline \multicolumn{2}{c}{ Physical analyses } \\
\hline Solids content $(\%$ by mass $)$ & $99 \pm 1$ \\
Glass Transition $\left({ }^{\circ} \mathrm{C}\right)$ & $\sim+9$ \\
Apparent density $\left(\mathrm{g} / \mathrm{cm}^{3}\right)$ & 0.45 to 0.60 \\
Particle size $(\mu \mathrm{m})$ & $80 \pm 10$ \\
\hline
\end{tabular}

Table 4. Physical characteristics of styrene-butadiene copolymer dispersion.

\begin{tabular}{lc}
\hline \multicolumn{2}{c}{ Physical analyses } \\
\hline Solids content $(\%$ by mass $)$ & $50 \pm 1$ \\
Viscosity (MPa.s) & $2,000-5,000$ \\
Glass Transition $\left({ }^{\circ} \mathrm{C}\right)$ & $\sim+3$ \\
Apparent density $\left(\mathrm{g} / \mathrm{cm}^{3}\right)$ & $1.0 \pm 0.1$ \\
Particle size $(\mu \mathrm{m})$ & $80 \pm 10$ \\
\hline
\end{tabular}

Table 5. Chemical analysis of carbonate filler.

\begin{tabular}{cc}
\hline Element & $(\%)$ \\
\hline $\mathrm{SiO}_{2}$ & 6.48 \\
$\mathrm{Al}_{2} \mathrm{O}_{3}$ & 1.67 \\
$\mathrm{Fe}_{2} \mathrm{O}_{3}$ & 1.10 \\
$\mathrm{MgO}$ & 18.8 \\
$\mathrm{CaO}$ & 31.6 \\
$\mathrm{Na}_{2} \mathrm{O}$ & $<0.10$ \\
$\mathrm{~K}_{2} \mathrm{O}$ & 0.40 \\
$\mathrm{SO}_{3}$ & 0.14 \\
\hline
\end{tabular}

Table 6. Chemical analysis of silica fume.

\begin{tabular}{cc}
\hline Element & $(\boldsymbol{\%})$ \\
\hline $\mathrm{SiO}_{2}$ & 93.5 \\
$\mathrm{Al}_{2} \mathrm{O}_{3}$ & 0.43 \\
$\mathrm{Fe}_{2} \mathrm{O}_{3}$ & 0.45 \\
$\mathrm{MgO}$ & 0.47 \\
$\mathrm{CaO}$ & 0.23 \\
$\mathrm{Na}_{2} \mathrm{O}$ & 0.16 \\
$\mathrm{~K}_{2} \mathrm{O}$ & 0.83 \\
$\mathrm{SO}_{3}$ & - \\
\hline
\end{tabular}

\subsection{General procedures}

The established compositions are shown in Table 7. For the analyzes of the influence of density, porosity and pore distribution on moisture movement of the composites, the range was formed by four compositions with different kinds of copolymer (A - without copolymer; B - styrene-acrylic addition; C - Va/Veova addition and D - styrene-butadiene addition).

The following procedure was employed for the mixing of fiber cements: (i) submission of the unrefined cellulose pulp to a stirring process in water and post-refining by several passes through $300 \mathrm{~mm}$ disc refiner until the achievement of CSF $220 \mathrm{~mL}$ refinement degree; (ii) dispersion of PVA fiber in water; (iii) dispersion of silica fume by ultrasonic equipment; (iv) mixing of all these materials in water; (v) addition of carbonate filler; (vi) addition of ordinary Portland cement; (vii) high-speed mechanical mixing during $300 \mathrm{~s}$; (viii) sheet molding by vacuum dewatering process; (ix) cutting of the specimens $(160 \mathrm{~mm} \times 40 \mathrm{~mm} \times 5 \mathrm{~mm})$ $24 \mathrm{~h}$ after production; (x) cure in water until the $28^{\text {th }}$ day of age; (xi) preparation of the specimens for physical and mechanical tests and mercury intrusion porosimetry (MIP).

\subsection{Physical and mechanical characterization tests}

Water absorption and bulk density results were obtained from the average of ten specimens for each formulation, following the procedures specified by ASTM C 948-8129. Mechanical (flexural) tests were performed in a universal testing machine Emic DL-30000 equipped with $5 \mathrm{kN}$ load cell. A span of $135 \mathrm{~mm}$ and a deflection rate of $5 \mathrm{~mm} / \mathrm{min}$ were adopted in the flexural test. The deflection during the bending test was collected by the deflectometer positioned in the down side of the specimen. Modulus of rupture (MOR) and toughness were obtained. The absorbed energy was calculated by the integration of the load-deflection curve to the point corresponding to a reduction in load carrying capacity to $50 \%$ of the maximum observed. Toughness was defined as the energy absorbed during the flexural test and divided by the cross sectional area of the specimen.

\subsection{Soak \& dry accelerated ageing cycles}

To study the influence of product age on the studied variables a soak \& dry accelerated ageing cycles test was employed. It involved comparative analysis of the physical properties (water absorption and bulk density - except moisture movements) and mechanical performance of the composites before and after this test. The specimens were repeatedly immersed in water at $20^{\circ} \mathrm{C} \pm 5^{\circ} \mathrm{C}$ during $170 \mathrm{~min}$, followed by interval of $10 \mathrm{~min}$, and then exposed to the temperature of $70{ }^{\circ} \mathrm{C} \pm 5^{\circ} \mathrm{C}$ for $170 \mathrm{~min}$ in a ventilated oven and final interval of $10 \mathrm{~min}$. This procedure is similar to ISO $8336^{30}$, however it was based on recommendations of the EN $494^{31}$ Standards and carried out in automated equipment for the application of the successive cycles. Each soak \& dry set represents one cycle and was performed by 100 times (i.e., 100 cycles). The moisture movements were measured thru the expansion and shrinkage of the fiber cements composites, before and after their exposition to the 
natural ageing of these materials (i.e., six months exposed to weathering).

\subsection{Water Sorption}

The expansion/shrinkage properties of the composites were monitored in a controlled environmental chamber. The relative humidity and temperature were pre-conditioned (70\% $\mathrm{RH}$ and $40{ }^{\circ} \mathrm{C}$ respectively) and kept constant by specific equipment (Thermotron). The specimens with 28 days of age were also pre-conditioned. A group of 20 specimens was established for each composition (A, $\mathrm{B}, \mathrm{C}$ and $\mathrm{D}$ as in Table 7) being the first ten specimens pre-conditioned by submerging in water for $48 \mathrm{~h}$ at $25^{\circ} \mathrm{C}$ and the other ten specimens dried in the temperature of $105^{\circ} \mathrm{C}$ by $48 \mathrm{~h}$. After these procedures, all specimens were positioned inside the chamber and their expansion/shrinkage measured each week by a digital caliper. The behavior of the specimens was then plotted in expansion/shrinkage versus time curves.

\subsection{Moisture movement}

For the determination of the moisture movement of the fiber cements, the specimens were pre-conditioned in the temperature of $105{ }^{\circ} \mathrm{C}$ by $48 \mathrm{~h}$. After this, they were cooled and measured by a digital caliper. Subsequently, the specimens were submerged in water at room temperature by $48 \mathrm{~h}$. The moisture movement was obtained as function of the linear changes based on the length at dry and saturated conditions.

\subsection{Mercury intrusion porosimetry (MIP)}

MIP analyses were carried out in a PoreSizer 9320 - Micromeritics equipment. At 28 days the specimens were cut with a diamond saw and submitted to ultrasonic cleaning equipment during $10 \mathrm{~min}$. The samples were initially removed and vacuum-oven-dried at $40^{\circ} \mathrm{C}$ for $24 \mathrm{~h}$. The porosimeter used for pore size distribution was able to apply a pressure of approximately $410 \mathrm{MPa}$. For the analysis of the results, the intruded mercury values (intruded mercury volume by sample mass, in $\mathrm{mL} / \mathrm{g}$ ) were arranged within four distinct pressure intervals corresponding to different pore size ranges. The selected pore size ranges permit a good approach to cement matrix properties based on intruded mercury volumes. According to literature ${ }^{9}$, these pore size ranges can be correlated to cement matrix properties as shown in Table 8 .

All analyses mentioned above were carried out in the Faculty of Animal Science and Food Engineering of Pirassununga (FZEA), Institute of Physics of São Carlos and in the Institute of Chemistry of São Carlos, University of São Paulo.

\section{Results and Discussion}

Table 7 shows the mixture proportions analyzed. Tables 9-13 show the results of analyses. Results of moisture movement are shown in Table 14.

As seen in Table 10, the copolymer additions not change water absorption of the fiber cements in the contents employed. It is unlike the literature for cementitious composites such as mortars and concretes reinforced by glass fiber ${ }^{24-27}$. The authors attribute this particular behavior to water excess for mixing and consequently vacuum form to simulate Hatschek process adopted by the industry. In this way, it turns not possible the formation of polymer film into matrices. Despite to be common the use of flocculent polymers in Hatschek process, there is not works in the literature about the use of these copolymers for fiber cement

Table 7. Mixture proportions (\% by mass).

\begin{tabular}{|c|c|c|c|c|c|c|c|}
\hline $\begin{array}{c}\text { Fiber } \\
\text { cement }\end{array}$ & $\begin{array}{c}\text { Ordinary } \\
\text { Portland } \\
\text { cement }\end{array}$ & $\begin{array}{l}\text { Silica } \\
\text { fume }\end{array}$ & $\begin{array}{l}\text { Carbonate } \\
\text { filler }\end{array}$ & $\begin{array}{l}\text { PVA } \\
\text { fiber }\end{array}$ & $\begin{array}{l}\text { Cellulose } \\
\text { fiber }\end{array}$ & $\begin{array}{c}\text { Copolymer } \\
(*)\end{array}$ & $\begin{array}{c}\text { Approximated } \\
\text { water/cement } \\
\text { ratio }\end{array}$ \\
\hline $\begin{array}{c}\text { A } \\
\text { without copolymer }\end{array}$ & 80 & 8 & 7 & 2 & 3 & - & 0.22 \\
\hline $\begin{array}{c}\text { B } \\
\text { styrene-acrylic }\end{array}$ & 80 & 8 & 7 & 2 & 3 & 2.7 & 0.22 \\
\hline $\begin{array}{c}\mathrm{C} \\
\mathrm{Va} / \text { Veova }\end{array}$ & 80 & 8 & 7 & 2 & 3 & 2.7 & 0.22 \\
\hline $\begin{array}{c}\text { D } \\
\text { styrene-butadiene }\end{array}$ & 80 & 8 & 7 & 2 & 3 & 2.7 & 0.22 \\
\hline
\end{tabular}

*Percentage of copolymer addition applied to the total dry mass.

Table 8. Classification of pore size in hydrated cement paste/fiber cement.

\begin{tabular}{ccc}
\hline Designation & Pore diameter & Properties affected/Relations \\
\hline Hydrated phases (gel) porosity & $<10 \mathrm{~nm}$ & Shrinkage and creep \\
Medium capillaries & $10-50 \mathrm{~nm}$ & Strength, permeability, creep and shrinkage \\
Large capillaries & $50 \mathrm{~nm}-1 \mu \mathrm{m}$ & Strength and permeability \\
Fiber/matrix voids & $300-800 \mathrm{~nm}$ & Cellulose fibers \\
Large capillaries/ entrained air & $>1 \mu \mathrm{m}$ & Strength \\
Fiber/matrix voids & $1.5 \mu \mathrm{m}$ & Unrefined cellulose fibers \\
Large fiber/matrix voids & $2 \mu \mathrm{m}$ & Fiber/matrix failure
\end{tabular}


Table 9. Mechanical properties at 28 days of age.

\begin{tabular}{cccccc}
\hline $\begin{array}{c}\text { Fiber } \\
\text { cement }\end{array}$ & $\begin{array}{c}\text { Modulus of rupture } \\
\text { MOR (MPa) }\end{array}$ & SD* & $\begin{array}{c}\text { Limit of } \\
\text { proportionality (MPa) }\end{array}$ & SD & $\begin{array}{c}\text { Toughness } \\
\left(\mathbf{k J} / \mathbf{m}^{2}\right)\end{array}$ \\
\hline A & 11.35 & 0.90 & 9.05 & 1.05 & 2.65 \\
B & 10.50 & 1.25 & 7.00 & 0.90 & 3.40 \\
C & 11.30 & 1.45 & 8.90 & 2.10 & 2.95 \\
D & 11.20 & 1.35 & 9.50 & 1.15 & 2.60 \\
\hline
\end{tabular}

*Standard deviation.

Table 10. Physical characteristics at 28 days of age.

\begin{tabular}{cccccc}
\hline $\begin{array}{c}\text { Fiber } \\
\text { cement }\end{array}$ & $\begin{array}{c}\text { Water } \\
\text { absorption (\%) }\end{array}$ & SD* & $\begin{array}{c}\text { Bulk density } \\
\left(\mathbf{g} / \mathbf{c m}^{\mathbf{3}}\right)\end{array}$ & $\begin{array}{c}\text { SD } \\
\text { SD }\end{array}$ & $\begin{array}{c}\text { Apparent } \\
\text { porosity }(\%)\end{array}$ \\
\hline A & 20.55 & 1.25 & 1.65 & 0.05 & 33.40 \\
B & 20.00 & 0.60 & 1.65 & 0.01 & 33.05 \\
C & 20.85 & 1.40 & 1.60 & 0.05 & 33.75 \\
D & 20.40 & 0.55 & 1.60 & 0.02 & 32.65 \\
\hline
\end{tabular}

*Standard deviation.

Table 11. Mechanical properties after soak \& dry cycles.

\begin{tabular}{cccccc}
\hline $\begin{array}{c}\text { Fiber } \\
\text { cement }\end{array}$ & $\begin{array}{c}\text { Modulus of rupture } \\
\text { MOR (MPa) }\end{array}$ & SD* & $\begin{array}{c}\text { Limit of } \\
\text { proportionality (MPa) }\end{array}$ & $\begin{array}{c}\text { Soughness } \\
\left(\mathbf{k J} / \mathbf{m}^{2}\right)\end{array}$ \\
\hline A & 11.50 & 1.00 & 9.85 & 1.45 & 1.25 \\
B & 11.25 & 0.35 & 9.05 & 1.05 & 1.80 \\
C & 10.55 & 0.80 & 9.80 & 1.35 & 1.65 \\
D & 12.90 & 1.20 & 11.60 & 2.00 & 1.80 \\
\hline
\end{tabular}

*Standard deviation.

Table 12. Physical characteristics after soak \& dry cycles.

\begin{tabular}{cccccc}
\hline $\begin{array}{c}\text { Fiber } \\
\text { cement }\end{array}$ & $\begin{array}{c}\text { Water } \\
\text { absorption }(\boldsymbol{\%})\end{array}$ & SD* & $\begin{array}{c}\text { Bulk density } \\
\left(\mathbf{g} / \mathbf{c m}^{\mathbf{3}}\right)\end{array}$ & SD & $\begin{array}{c}\text { Apparent } \\
\text { porosity }(\boldsymbol{\%})\end{array}$ \\
\hline A & 18.50 & 0.80 & 1.65 & 0.03 & 30.70 \\
B & 20.65 & 1.20 & 1.55 & 0.03 & 32.20 \\
C & 18.00 & 1.45 & 1.65 & 0.04 & 29.40 \\
D & 17.00 & 2.20 & 1.62 & 0.06 & 27.70 \\
\hline
\end{tabular}

*Standard deviation.

Table 13. Results from porosimetry analyses.

\begin{tabular}{|c|c|c|c|c|c|c|}
\hline $\begin{array}{c}\text { Fiber } \\
\text { cement }\end{array}$ & $\begin{array}{l}\text { Opened porosity } \\
\text { at } 28 \text { days }(\%)\end{array}$ & $\begin{array}{l}\text { Opened porosity } \\
6 \text { months old }(\%)\end{array}$ & $\begin{array}{l}\text { Real density at } \\
28 \text { days }\left(\mathrm{g} / \mathrm{cm}^{3}\right)\end{array}$ & $\begin{array}{c}\text { Real density } 6 \\
\text { months old }\left(\mathrm{g} / \mathrm{cm}^{3}\right)\end{array}$ & $\begin{array}{l}\text { Mean diameter } \\
\text { at } 28 \text { days }(\mu \mathrm{m})\end{array}$ & $\begin{array}{c}\text { Mean diameter } \\
6 \text { months old }(\mu \mathrm{m})\end{array}$ \\
\hline A & 6.53 & 6.17 & 1.64 & 1.64 & 0.0243 & 0.0501 \\
\hline B & 7.64 & 6.70 & 1.53 & 1.62 & 0.0312 & 0.0423 \\
\hline $\mathrm{C}$ & 7.62 & 5.48 & 1.63 & 1.76 & 0.0269 & 0.0406 \\
\hline D & 7.52 & 6.13 & 1.59 & 1.70 & 0.0361 & 0.0620 \\
\hline
\end{tabular}

formulations. In this way, these copolymers appear not to be appropriated to this process and probably the polymer matrix phase it was not made into cement hydrate phase. Considering the results of porosimetry, it turns evident because as known the use of polymers decrease the pore diameters. Table 13 not evidences this behavior.

However, the principal aim of copolymer addition was accomplished, that is, changes in the density and porosity variables as showed in the Table 13 . The mercury intrusion porosimetry (MIP) showed to be an important technique to measure the influence of the copolymers in these variables.
In relation to flexural tests, all copolymer additions increased the toughness of the fiber cements as described by the literature ${ }^{3}$. It was also observed that the soak and dry procedure decreased the energy absorption of the composites. These results have probably correlation to copolymer degradation in the alkaline environment of Portland cement matrices and the increasing of Young's modulus of these composites from densification of the matrixes as showed in Table 13.

Figures 1-8 show the moisture sorption of the fiber cements under evaluation. It is pointed out that movement of water within composites is very complex. Regardless 
Table 14. Moisture movement.

\begin{tabular}{ccccc}
\hline $\begin{array}{c}\text { Fiber } \\
\text { cement }\end{array}$ & $\begin{array}{c}\text { Moisture } \\
\text { movement at } \\
\text { 28 days (mm/m) }\end{array}$ & SD $^{*}$ & $\begin{array}{c}\text { Moisture } \\
\text { movement at } \\
\text { 6 months (mm/m) }\end{array}$ & SD \\
\hline A & 2.0 & 0.1 & 4.0 & 0.4 \\
B & 1.4 & 0.1 & 4.3 & 0.3 \\
C & 2.1 & 0.3 & 3.8 & 0.2 \\
D & 1.9 & 0.2 & 2.4 & 0.4 \\
\hline
\end{tabular}

*Standard deviation.

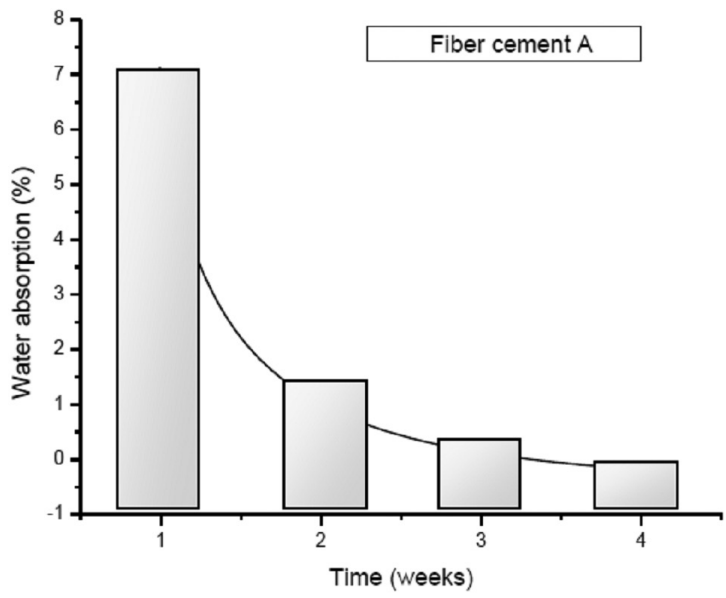

Figure 1. Water absorption evolution up to 28 days - fiber cement A.

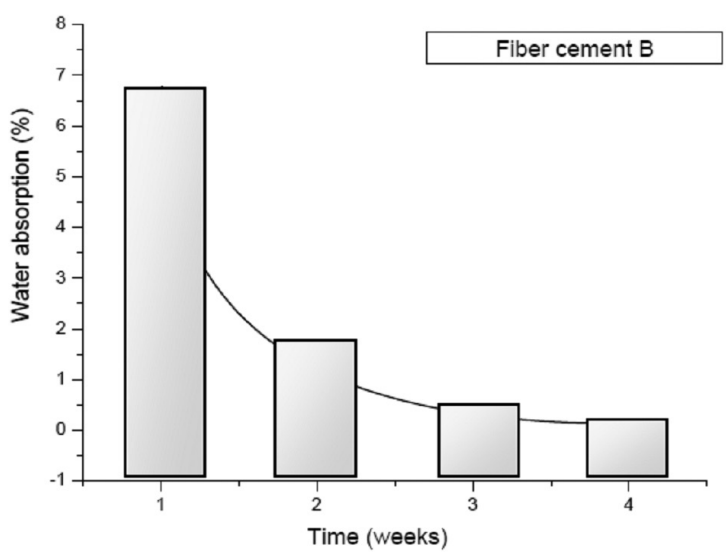

Figure 2. Water absorption evolution up to 28 days - fiber cement B.

of this, the composites performed hygral behavior with intensive loss of water and water adsorption during the first weeks and tendency to be close to zero after certain period of time. For the conditions established in the present study, this stabilization was observed after four weeks.

The moisture movements perform the principal target of this study and are showed in Table 14. The changes in the variables density and porosity made composites with different properties. Both the bulk density and the water absorption strongly influence the moisture expansion/ shrinkage of the asbestos-free fiber cement. On the other hand, the total porosity did not show to be very important.

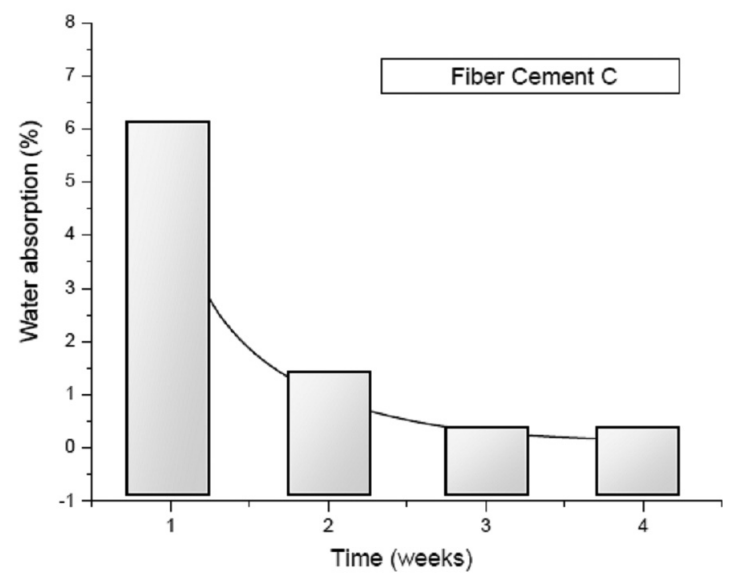

Figure 3. Water absorption evolution up to 28 days - fiber cement C.

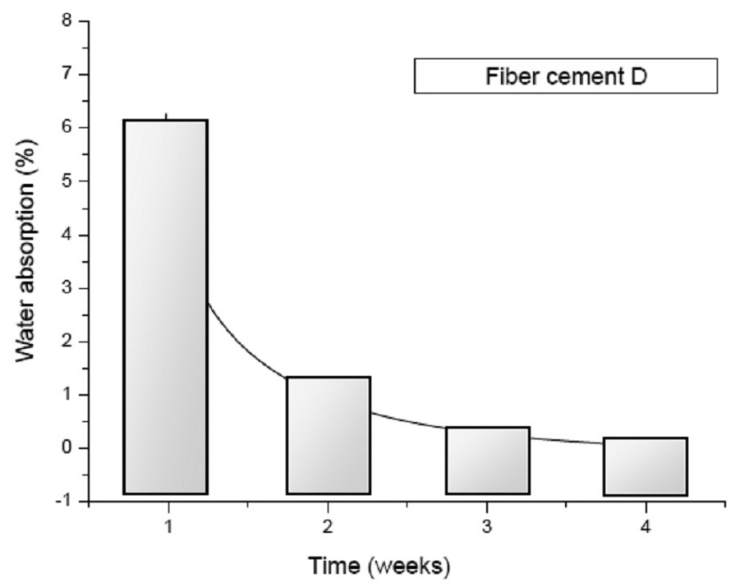

Figure 4. Water absorption evolution up to 28 days - fiber cement D.

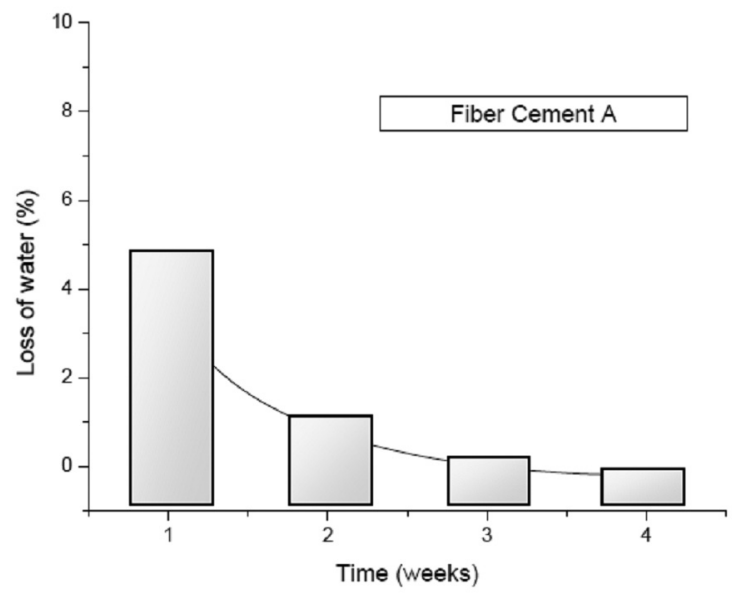

Figure 5. Loss of water evolution up to 28 days - fiber cement A.

Despite of that, the pore structure or pore size distributions showed to be the most important characteristic in the control of moisture movement of these composites.

Figures 9-16 show the curves of intruded mercury volume in function of pore diameter (incremental volume) for the fiber cements under analyses. Pore size distribution 


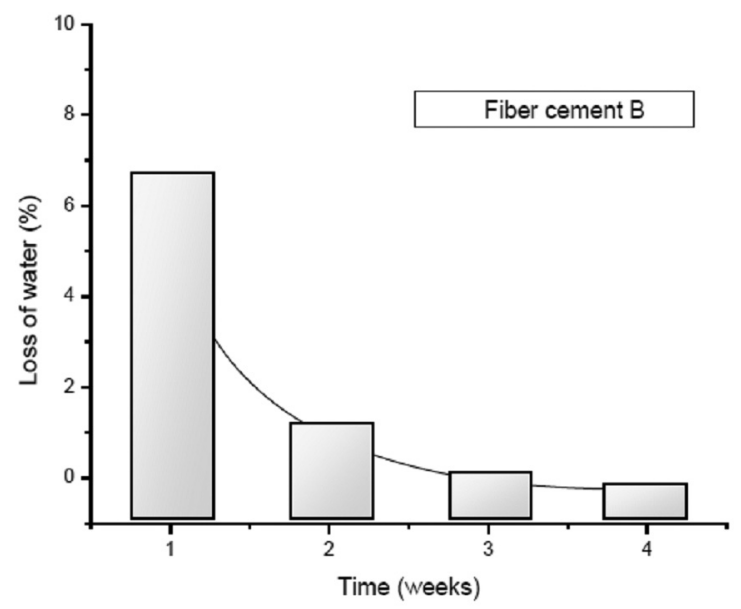

Figure 6. Loss of water evolution up to 28 days - fiber cement B.

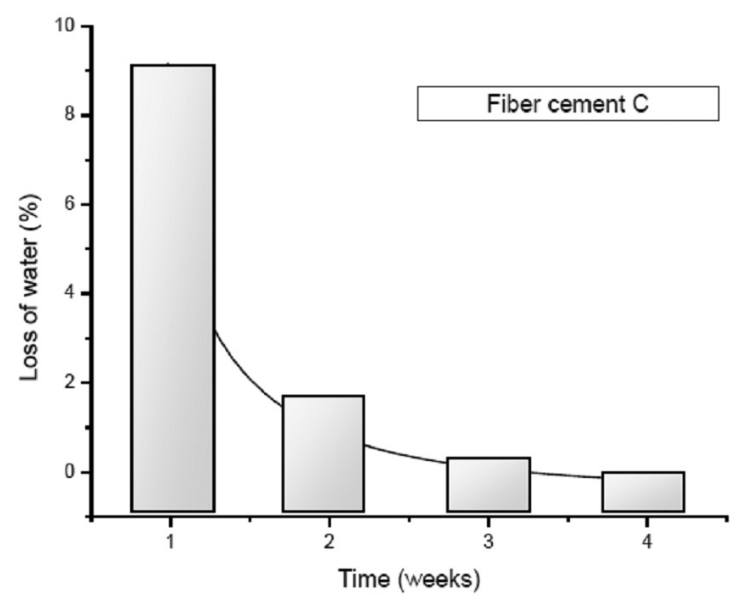

Figure 7. Loss of water evolution up to 28 days - fiber cement C.

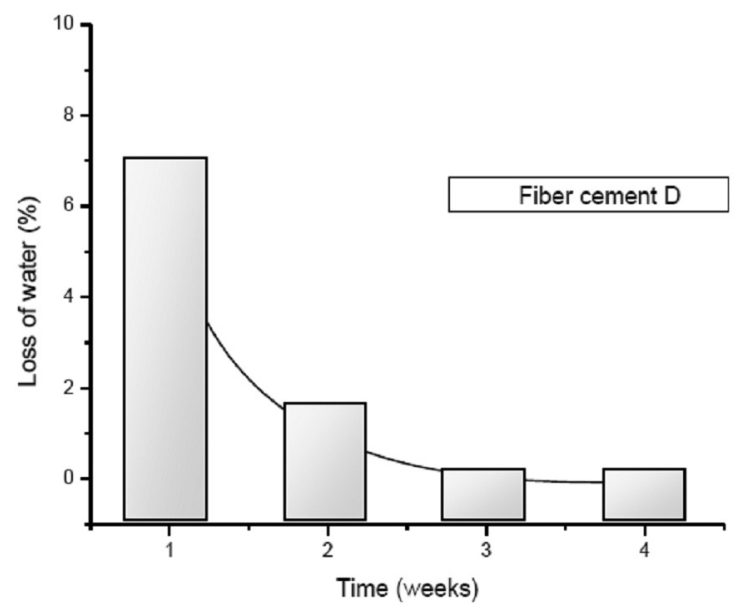

Figure 8. Loss of water evolution up to 28 days - fiber cement D.

curves exhibit several characteristic peaks showed in Table 8 . The peaks around $3-10 \mathrm{~nm}$ and $40-100 \mathrm{~nm}$ are related to pores of gel (hydrated phases) and medium capillaries respectively. These peaks showed to be higher at 28 days than after 6 months of age. Probably, these results are from matrix carbonation and continued hydration of

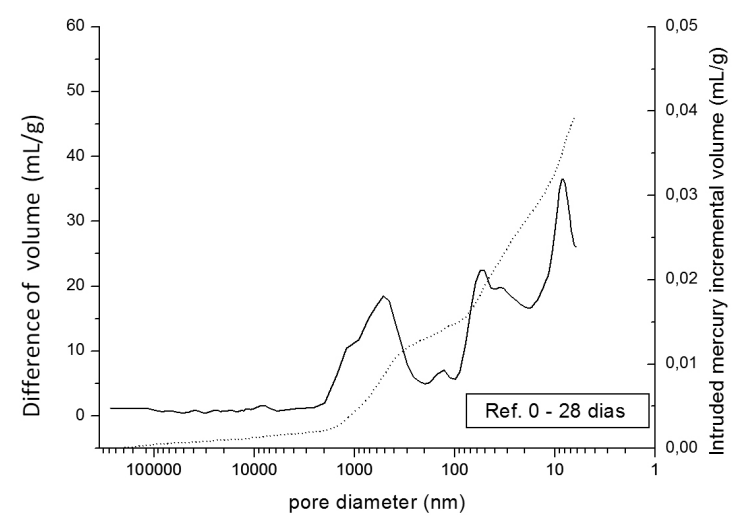

Figure 9. Porosimetry of fiber cement A at 28 days.

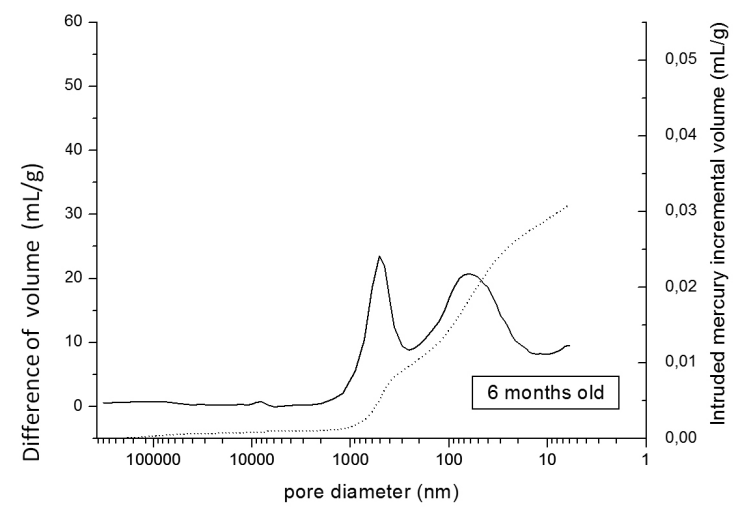

Figure 10. Porosimetry of fiber cement A at six months of age.

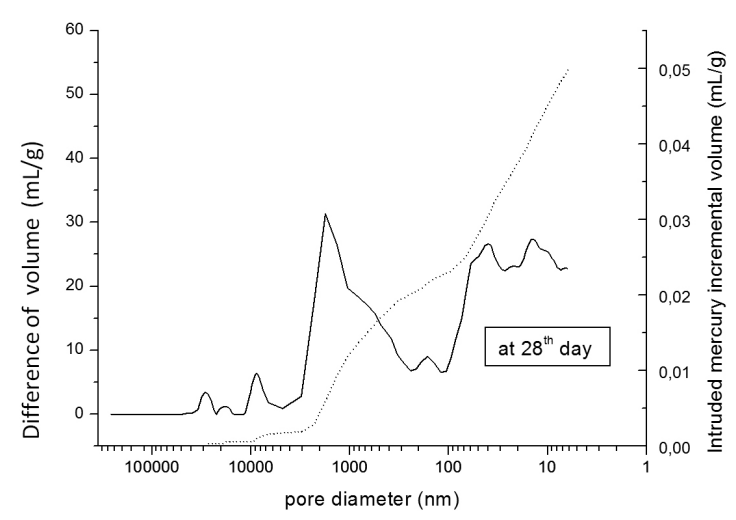

Figure 11. Porosimetry of fiber cement B at 28 days.

ordinary Portland cement phases. The decrease of these peaks showed correlation to the increment of moisture expansion/shrinkage of the analyzed composites. The peaks around $1-5 \mu \mathrm{m}$ are probably from voids in the fiber/matrix interface. These peaks showed to be higher in the composites of lower moisture movements.

The density of the non-asbestos fiber cement plays a very important role in the moisture expansion/shrinkage of these composites like their pore structures or pore distribution. 


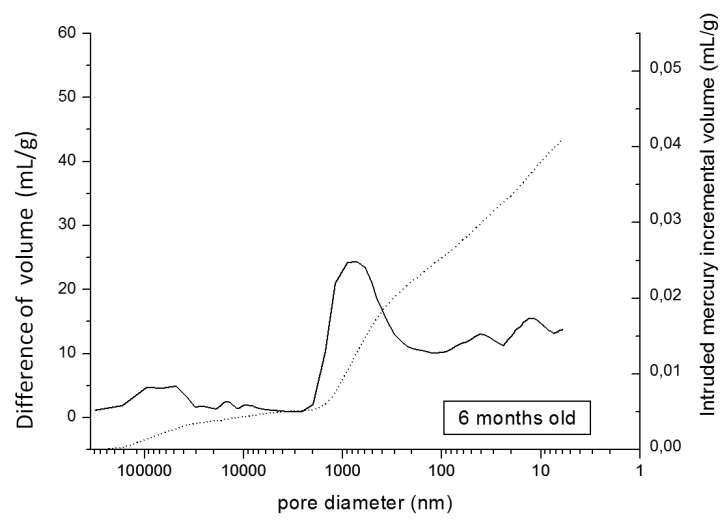

Figure 12. Porosimetry of fiber cement $B$ at six months of age.

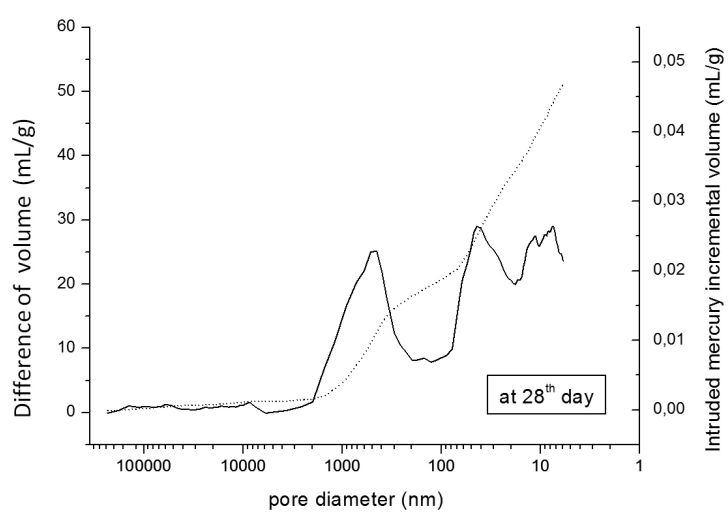

Figure 13. Porosimetry of fiber cement $\mathrm{C}$ at 28 days.

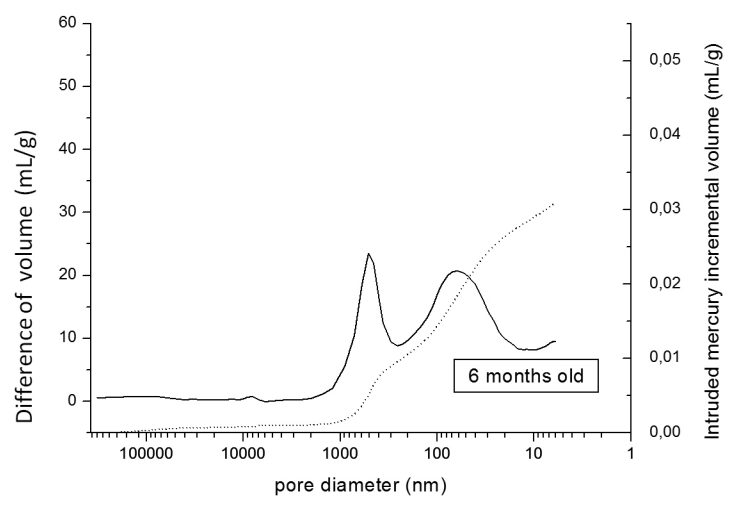

Figure 14. Porosimetry of fiber cement $\mathrm{C}$ at six months of age.

Although the hygral behavior of the fiber cements is very complex, concluding remarks are showed below:

- Migration of the pore water of fiber cements can be related to the density;

- Moisture movements (expansion/shrinkage) are related to water absorption and density of these materials and also not strongly related to total porosity;

- Density and porosity are related to each other; however, for products of equivalent density having different pore distribution, the pore structure appeared

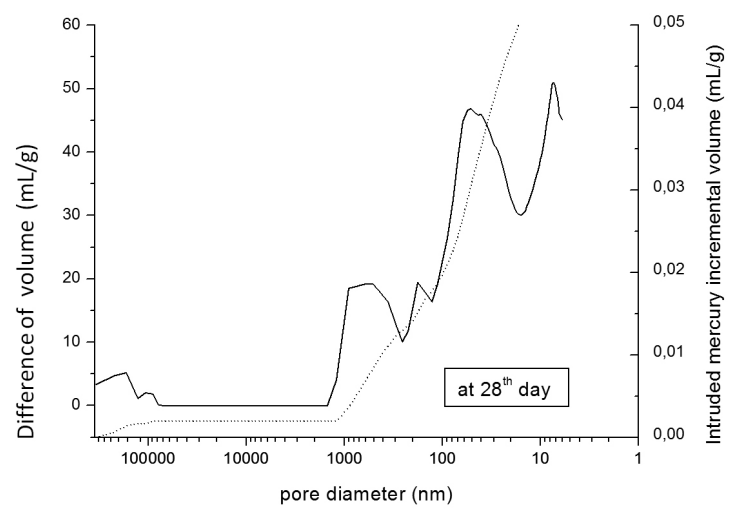

Figure 15. Porosimetry of fiber cement D at 28 days.

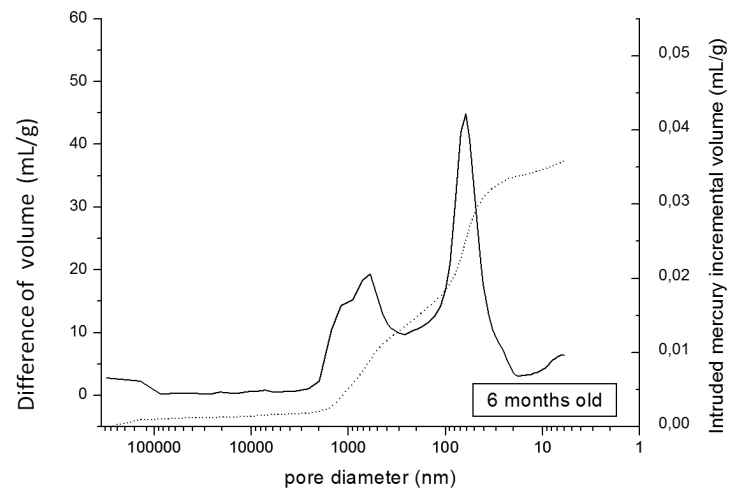

Figure 16. Porosimetry of fiber cement D at six months of age.

to be the most important characteristics to the moisture movements;

- The capillary pores around 40-100 nm have strong influence in the hygral behavior of these composites when exposed to weather;

- The hydration during the time of the non-hydrated phases of cement paste and carbonation may increment the expansion/shrinkage of these composites;

- The pores around 1-5 $\mu \mathrm{m}$ probably relate to voids in the fiber/matrix interface and may collaborate to decrease of expansion/shrinkage of asbestos-free fiber cements;

- The use of copolymers in the Hastschek process is not sufficient to control the moisture movement and expansion/shrinkage of this cementitious composite.

\section{Acknowledgments}

The authors acknowledge the support of The Institute of Chemistry of São Carlos, The Institute of Physics of São Carlos and specially The Faculty of Animal Science and Food Engineering (FZEA), Department of Food Engineering, Environmental Buildings Group, Pirassununga, University of São Paulo, Brazil. The authors are also in debt with The National Council for Scientific and Technological Development- CNPq due to the offered to the development of the research. 


\section{References}

1. Arkers S and Partl M. Hygral and Thermal Expansion/ Shrinkage Properties of Asbestos-Free Fibre Cement. Cement and Concrete Composites. 1990; 12:19-27. http://dx.doi. org/10.1016/0958-9465(90)90032-S

2. Savastano H and Agopyan V. Transition Zone Studies of vegetable fibre-cement paste composites. Cement and Concrete Composites. 1999; 21:40-57. http://dx.doi.org/10.1016/S09589465(98)00038-9

3. Bentur A and Mindess S. Fibre Reinforced Cementitious Composites. London: Elsevier Applied Science; 1990. 449 p.

4. Chandra S and Flodin P. Interactions of polymers and organic admixtures on Portland Cement Hydration. Cement Concrete Research. 1990; 17:975-890.

5. Ohama Y. Polymer-base admixtures. Cement and Concrete Composites. 1998; 20:189-212. http://dx.doi.org/10.1016/ S0958-9465(97)00065-6

6. Ohama Y. Recent Progress in Concrete-Polymer Composites. Advn. Cement Bas. Materials. 1997; 5:31-40.

7. Fowler DW. Polymers in concrete: a vision for the 21 st century. Cement and Concrete Composites. 1999; 21:449-452,. http:// dx.doi.org/10.1016/S0958-9465(99)00032-3

8. Kong XM and Li QH. Properties and microstructure of polymer modified mortar based on different acrylate latexes. Journal of the Chinese Ceramic Society. 2009; 37(1):107-14.

9. Zhang Z, Wang P and Wu J. Dynamic Mechanical Properties of EVA Polymer-Modified Cement Paste at Early Age. Physics Procedia. 2012; 25:305-310. http://dx.doi.org/10.1016/j. phpro.2012.03.088

10. Wang R, Wang PM and Li XG. Physical and mechanical properties of styrene-butadiene rubber emulsion modified cement mortars. Cement and Concrete Composites. 2005; 35:900-6. http://dx.doi.org/10.1016/j.cemconres.2004.07.012

11. Wang R and Wang PM. Physical properties of SBR latexmodified mortar under different curing methods. Journal of the Chinese Ceramic Society. 2009; 37(12):2118-23.

12. Wang R and Wang PM. Function of styrene-acrylic ester copolymer latex in cement mortar. Materials and Structures. 2010; 43:443-51. http://dx.doi.org/10.1617/s11527-0099501-3

13. Wang $\mathrm{R}$ and Wang PM. Action of redispersible vinyl acetate and versatate copolymer powder in cement mortar. Construction and Building Materials. 2011; 25:4210-4214 http://dx.doi.org/10.1016/j.conbuildmat.2011.04.060

14. Gomes CEM and Ferreira OP. Analyses of Microstructural Properties of VA/VeoVA Copolymer Modified Cement Pastes. Polímeros. 2005; 15(3). http://dx.doi.org/10.1590/S010414282005000300009

15. Wang PM, Zhang GF and Zhang YM. Influence of polymer powders on mechanical properties of cement mortar. New Build Materials. 2005; 1:32-6.

16. Afridi MUK, Ohama Y, Demura K, Iqbal MZ. Development of polymer films by the coalescence $\mathrm{f}$ polymer particles in powdered and aqueous polymer modified mortars. Cement and Concrete Composites. 2003; 33:1715-21. http://dx.doi. org/10.1016/S0008-8846(02)01094-3

17. Jansen L, Götz-Neunhoeffer F, Neubauer J, Haerzschel R and Hergeth W-D. Effect of polymers on cement hydration: A case study using substituted PDADMA. Cement and Concrete Composites. 2013; 35:71-77. http://dx.doi.org/10.1016/j. cemconcomp.2012.08.022

18. Nestle N, Kühn A, Friedemann K, Horch C, Stallmach F and Herth G. Water balance and pore structure development in cementitious materials in internal curing with modified superabsorbent polymer studied by NMR. Microporous and Mesoporous Materials. 2009; 125:51-7. http://dx.doi. org/10.1016/j.micromeso.2009.02.024

19. Zhang GF, Wang PM and Wu JG. Influence of polymer powder on the bulk density and capillary water adsorption of cement mortar. New Build Materials. 2004:29-31.

20. Ollitrault-Fichet R, Gauthier C, Calmen G and Boch P. Microstructural aspects in a polymer-modified cement. Cement and Concrete Research. 1998; 28(12):1687-1693. http://dx.doi. org/10.1016/S0008-8846(98)00153-7

21. Knapen E and Gemert DV. Cement hydration and microstructure formation in the presence of water-soluble polymers. Cement and Concrete Research. 2009; 39:6-13. http://dx.doi. org/10.1016/j.cemconres.2008.10.003

22. Stark J. Recent advances in the field of cement hydration and microstructure analysis. Cement and Concrete Research. 2011; 41:666-678. http://dx.doi.org/10.1016/j. cemconres.2011.03.028

23. Bentur A and Mindess S. Fibre Reinforced Cementitious Composites. Modern Concrete Technology Series. 2006

24. Ball HP. The effect of Forton compound on GFRC curing requirements. In: Proceedings 4th Biennial Congress of the GRCA; 1993; Stratford-upon-Avon. Stratford-upon-Avon; 1983. p. $56-65$.

25. Bijen J. Curing of GRC. In: Proceedings 6th Biennial International Congress of the GRCA; 1987; Edinburgh. Edinburgh; 1987, p. 71-77.

26. Bijen J. Polymer modified glass fibre reinforced cement (Polymermodifizierter [22] Glasfaserbeton). Concrete Precastingand Technology. 1989; 12:44-51.

27. Bijen J and Jacobs MJN. Properties of Glass Fiber Reinforced, Polymer Modified Cement. Journal of Material and Structures. $1981 ; 15(89): 445-452$.

28. European Standards. EN 197-1 - Cement (Part 1): Composition, specifications and conformity criteria for common cements. EN; 2001.

29. American Society for Testing and Materials. ASTM C 948-81: Standard Test Method for Dry and Wet Bulk Density, Water Absorption, and Apparent Porosity of Thin Sections of GlassFiber Reinforced Concrete. ASTM; 2009.

30. International Organization for Standardization. ISO 8336 : Fibre-cement flat sheets. Product specification and test methods. ISO; 2009.

31. European Standards. EN 494: Fibre-cement profiled sheets and fittings. Product specification and test methods. EM; 2004. 